\title{
Los Grabados populares de Álvaro Barrios y su relación con los ready-made de Marcel Duchamp
}

\section{Artículo de investigación}

\section{Albeiro Arias}

Universidad del Tolima, Colombia albeiroarias@ut.edu.co

Recibido: octubre 2 de 2018

Aprobado: 10 de diciembre de 2018

Cómo citar este artículo: Arias, Albeiro (2019). Los Grabados populares de Álvaro Barrios y su relación con los ready-made de Marcel Duchamp. Calle 14: revista de investigación en el campo del arte 14(26). pp. 296-313. DOI: https://doi.org/10.14483/21450706.15014 


\section{มL LYUL世อ}

Medellín-Colombia, Martes 5 de Junio de 1979

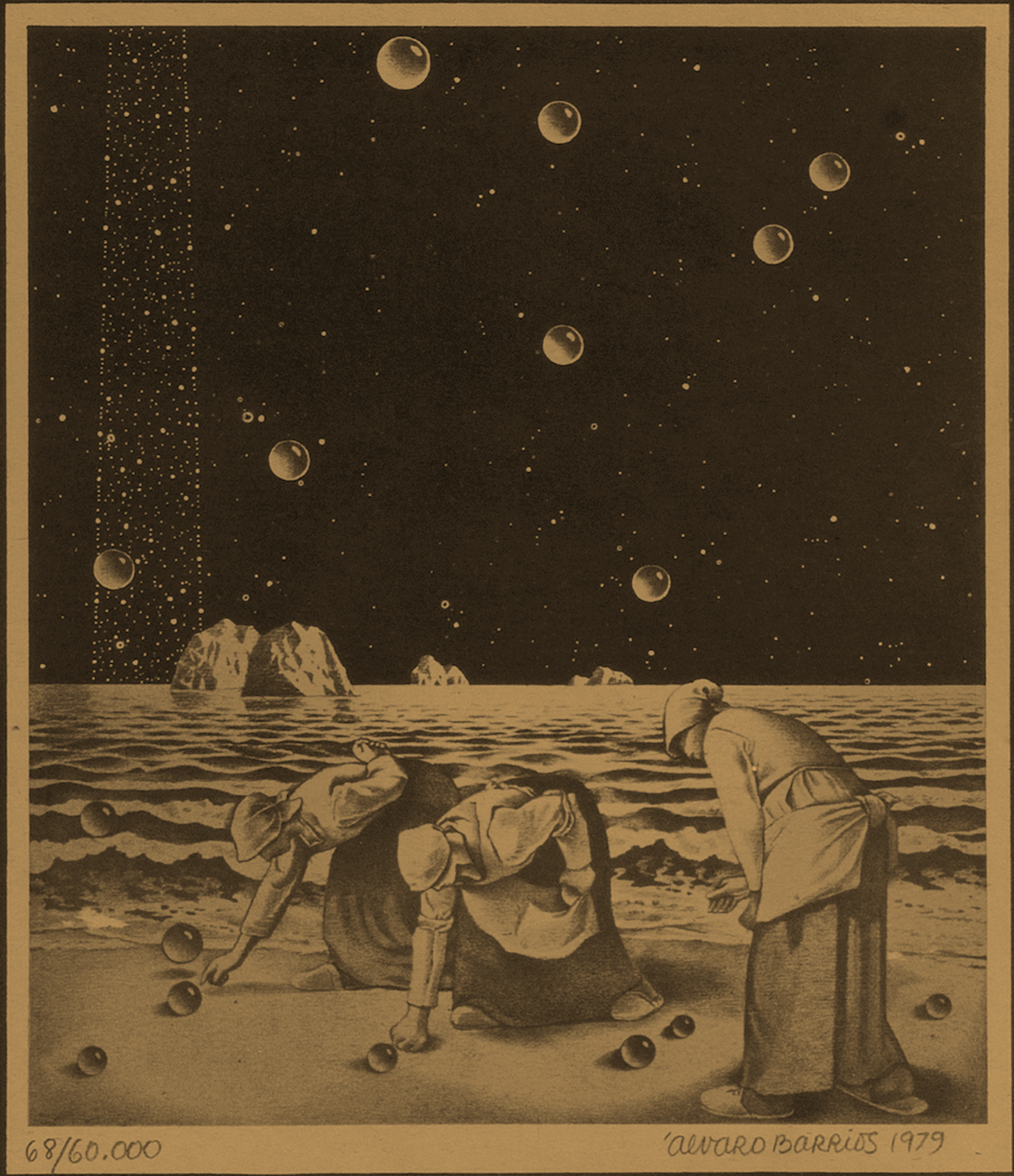




\title{
Resumen
}

El presente ensayo, aborda los Grabados populares de Álvaro Barrios para establecer sus orígenes, desarrollo y aportes a la historia del grabado colombiano. Para ello, se hará un recorrido por algunas de las series más conocidas para definir el concepto de Grabado popular, sus características principales y diferencias frente al grabado tradicional, dilucidar cómo "expande" el concepto de grabado y establecer la relación conceptual con el ready-made de Marcel Duchamp.

\section{Palabras clave}

Álvaro Barrios; Grabados populares; arte conceptual

The "Grabados populares" of Álvaro Barrios and Their Relationship With Marcel Duchamp's Readymades

\begin{abstract}
This essay addresses the collection of print series of Álvaro Barrios "Grabados populares" in order to establish their origins, development and contributions to the history of Colombian engraving. We will take a tour through some of the better-known series to define the concept of "grabado popular", popular engraving, its main characteristics and departures from traditional engraving. We will then elucidate how it "expands" the concept of engraving and seek to establish a conceptual relationship with Marcel Duchamp's ready-mades.
\end{abstract}

\section{Keywords}

Álvaro Barrios; Grabados populares; conceptual art

Les « Grabados populares » d'Álvaro Barrios et leur relation avec les Ready-made de Marcel Duchamp

\section{Résumé}

Cet essai porte sur la collection de séries d'impressions d'Alvaro Barrios « Grabados populares » afin d'établir leurs origines, leur développement et leur contribution à l'histoire de la gravure colombienne. Nous ferons un tour dans certaines des séries les plus connues pour définir le concept de «gravure populaire », ses caractéristiques principales et ses différences avec la gravure traditionnelle. Nous verrons ensuite comment ce concept « élargit » celui de gravure et chercherons à établir une relation conceptuelle avec les Ready-made de Marcel Duchamp.

\section{Mots clés}

Álvaro Barrios ; Grabados populares ; art conceptuel

Os "Grabados populares" de Álvaro Barrios e sua relação com os ready-mades de Marcel Duchamp

\section{Resumo}

Este ensaio aborda a coleção de séries impressas de Álvaro Barrios "Grabados populares", a fim de estabelecer suas origens, desenvolvimento e contribuições para a história da gravura colombiana. Faremos um tour por algumas das séries mais conhecidas para definir o conceito de "gravura popular", suas principais características e desvios da gravura tradicional. Vamos então elucidar como isso "expande" o conceito de gravura e procuraremos estabelecer uma relação conceitual com os ready-mades de Marcel Duchamp.

\section{Palavras-chave}

Álvaro Barrios; Grabados populares; arte conceitual 


\section{Maillallachiska}

Kai ensayok, kallarimi chi gravadukuna Alvaro Barriospa kauangapa imasa kallariska ruraska i aidaska antiua gravado Colombiape. Chasapak ruranme sug purii naipe mas regseskapi kauangapa chi gravado papilar kuna, chi gravado tradicionalpe, Rimangapa imamanda imasami "achkaia" chi gravado kauangapa chi Ready- made de Marcel Duchamp.

\section{Rimangapa Ministidukuna}

Alvaro Barrios; grabados populares; suma rurag conceptual 


\section{Introducción}

Este artículo surge de la tesis doctoral Álvaro Barrios: cita y apropiación de los ready-made de Marcel Duchamp de 1978- 2013, presentada como requisito para optar al título de Doctor en Artes con mención en Artes Visuales de la Pontificia Universidad Católica de Chile y que tiene como propósito analizar, caracterizar y categorizar los discursos, estrategias y procedimientos usados por el artista conceptual, grabador y dibujante colombiano Álvaro Barrios (27 de octubre de 1945) cuando incurre en la apropiación iconográfica de los ready-made realizados por Marcel Duchamp en la producción de sus obras.

Quizá, de los máximos aportes de Álvaro Barrios a la historia del arte colombiano son los Grabados populares, con los cuales recibió importantes reconocimientos a nivel internacional: Medalla de Oro en la IX Bienal de Tokio (1974) por el grabado publicado el 3 de octubre de 1974 en el Diario del Caribe de Barranquilla y el Gran Premio en la I Trienal Latinoamericana de Grabado de Buenos Aires (1979) por un grabado publicado el 5 de junio del mismo año en el periódico El Mundo de Medellín. Invitado a múltiples eventos y exposiciones a nivel mundial sobre el grabado. Una gran parte de sus Grabados populares fue adquirida en el 2005 por el Museo de Arte Moderno de Nueva York
(MoMA) al considerar que Barrios expande el concepto y el alcance del grabado para la historia del arte. Sin embargo, son escasos los estudios que se ocupan del Grabado popular en particular y hasta donde se pudo constatar, a pesar que desde la publicación del Grabado popular Sueños con Marcel Duchamp en el Diario del Caribe de Barranquilla el 1 de octubre de 1978, Barrios inició su obsesión por citar o apropiarse de la obra de Duchamp, hasta ahora no se ha relacionado el elemento conceptual de los Grabados populares con los conceptos duchampianos.

\section{Origen del grabado popular}

En el libro Orígenes del arte conceptual en Colombia: 1968-1978 (2011), en el capítulo "Los Grabados Populares" (pp. 83-86) y en la entrevista concedida para esta investigación el 29 de enero de $2016,{ }^{1}$ Barrios explica que en 1972, trabajaba en la agencia de publicidad Sonovista (Barranquilla) de Fernando Dávila López. Le encargaron una campaña publicitaria para Café Puro Almendra Tropical que celebraba su aniversario número $45^{\circ}$. Se trataba de tres dibujos para igual número de periódicos de la ciudad de Barranquilla, mostrando

1 Arias, A. (2016). Entrevista personal a Álvaro Barrios el 29 de enero de 2016. Barranquilla, Colombia.
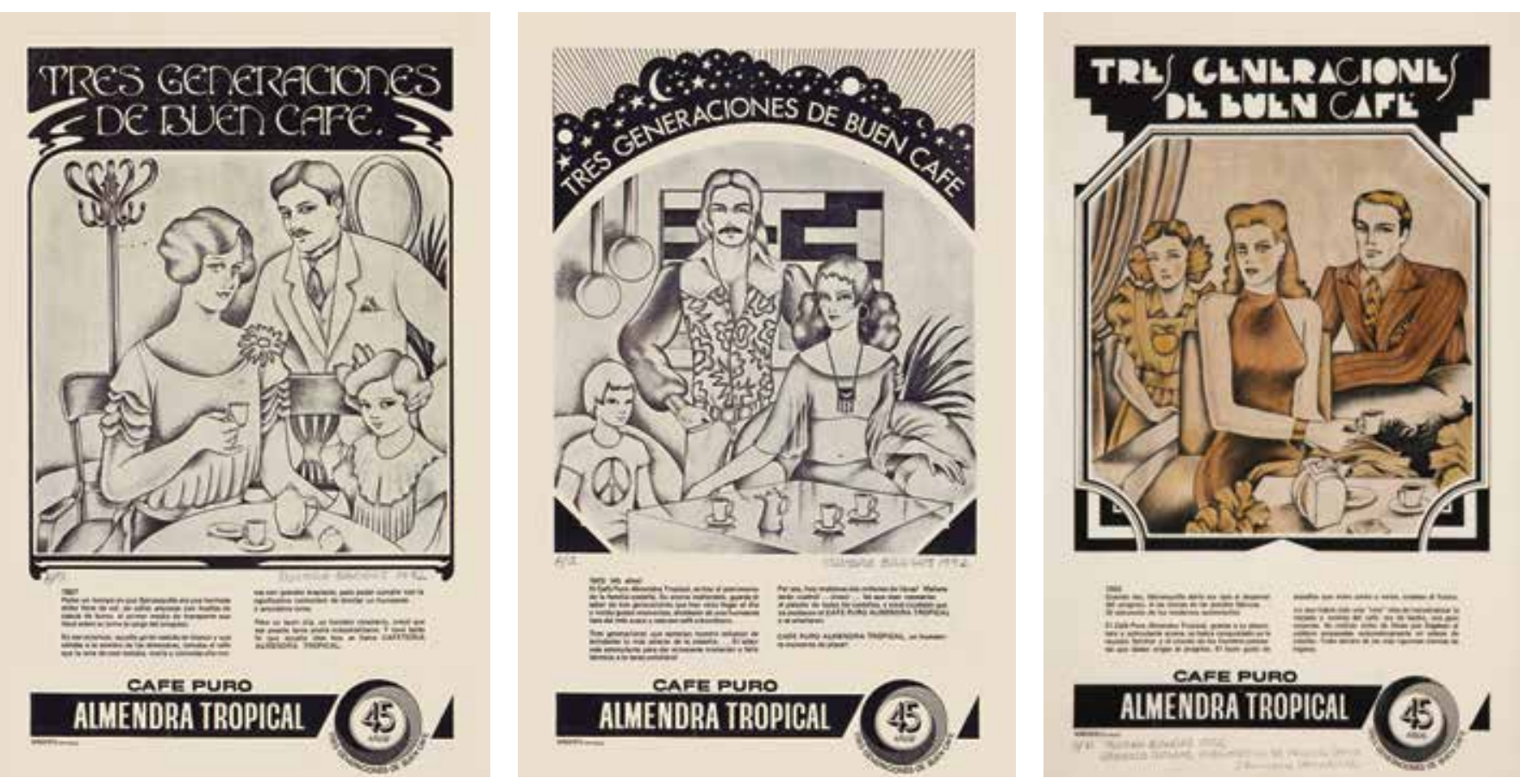

Imagen 1. Tres generaciones de buen café. (Álvaro Barrios, 1972). Primera serie de Grabados populares. (Tercer grabado intervenido con acuarela). Publicada por el Diario del Caribe, El Nacional y El Heraldo, Barranquilla. Cortesía del artista. 


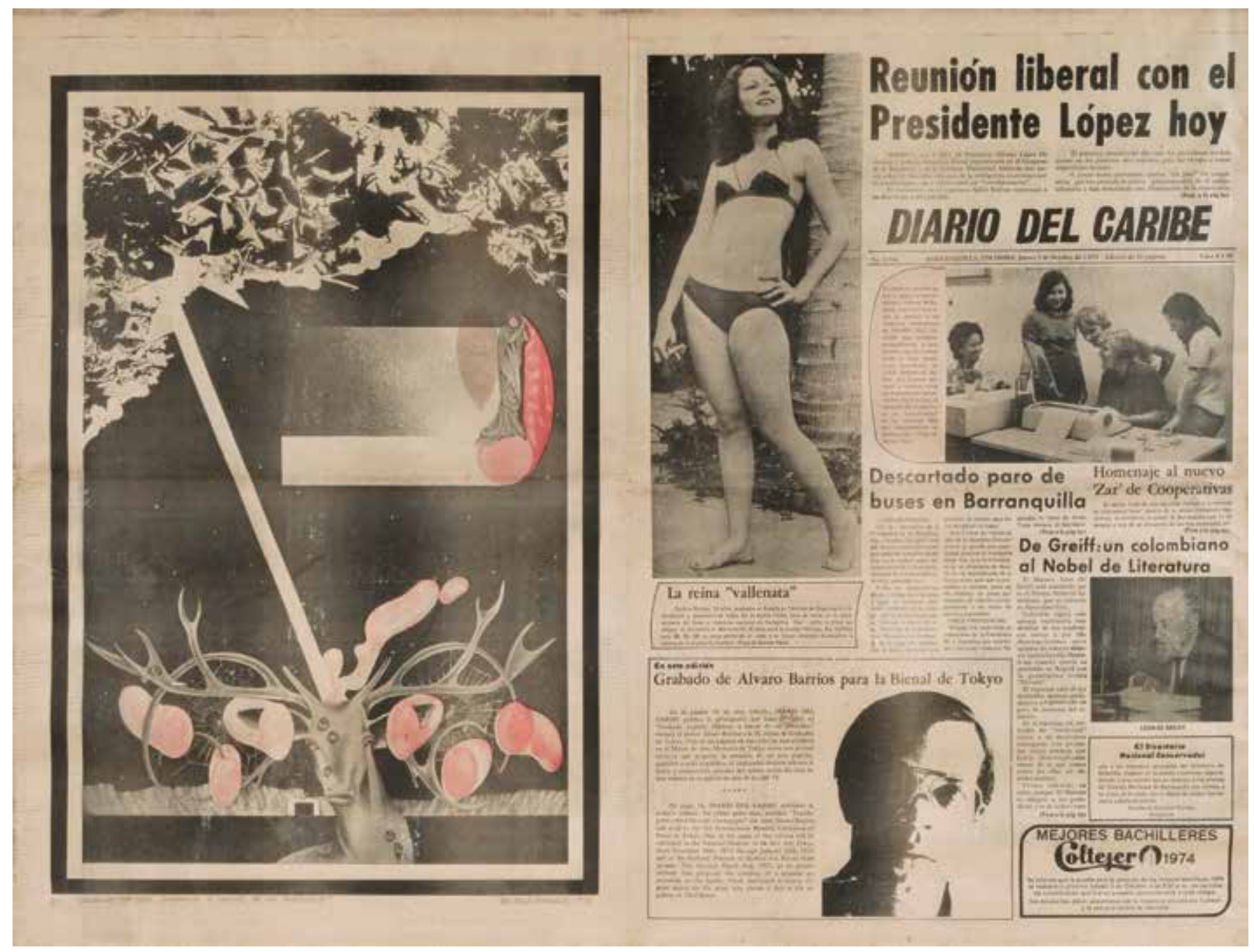

Imagen 2. Grabado Popular (Álvaro Barrios, 3 de octubre de 1974). Publicado en el Diario del Caribe, Barranquilla. Cortesía del artista.

tres generaciones de personas tomando café. Barrios para esa época ya gozaba de reconocimiento a nivel nacional y por ello, accedió a realizar los dibujos pero no a firmarlos, pues esto implicaba un beneficio para dicha empresa de su nombre como artista. Si ellos deseaban su firma deberían pagar un costo adicional. Este asunto lo hizo reflexionar sobre la cuestión de la firma. Efectivamente, realizó los dibujos a lápiz pero se los devolvieron en el periódico porque en la pruebas para la prensa se perdían muchos detalles, teniendo en cuenta que los periódicos no contaban con la actual tecnología como la impresión offset y los computadores, por lo tanto, debían hacerse clichés de los dibujos originales. Los realizó nuevamente, pero haciendo los contrastes, las luces y las sombras mucho más fuertes. A pesar de las preocupaciones del artista salieron los anuncios publicitarios con el tono y la traducción exacta de lo que él hacía en sus dibujos. Esto lo llevó a especular sobre el grabado tradicional, si la serigrafía podría considerarse una forma de grabado o no, y por el uso del término grabado: "estuve meditando sobre muchos términos usados en el arte contemporáneo que no revisten estrictamente el sentido que originalmente tuvieron y se aplican por extensión a otras formas de expresión análogas o paralelas" (Barrios, 2011, p. 83).

La serie de tres dibujos publicitarios para el Café Puro Almendra Tropical son publicados en los periódicos de Barranquilla El Heraldo, El Nacional y El Diario del Caribe (Imagen 1) y, posteriormente, junto a sus amigos Álvaro Cepeda Samudio, ${ }^{2}$ director del Diario del Caribe, y el periodista Julio Roca Baena, ${ }^{3}$ decide entronizarlos a

2 (Barranquilla, 30 de marzo de 1926 - Nueva York, 12 de octubre de 1972). Escritor y periodista colombiano. Editor del Diario del Caribe de 1961 a 1972. Se destacan su libro de cuentos Todos estábamos a la espera y la novela La casa grande.

$3 \quad$ Nacido en Barranquilla en 1935 y fallecido en esta misma ciudad en 1992. Periodista, traductor, pintor y melómano. Fue subdirector del Diario del Caribe durante muchos años. 
nivel de obra de arte al declararlos como grabados en un comunicado. Roca hizo un reportaje en el que aseguraba que los avisos eran en realidad obras de arte y que las personas que los recuperaran podían acercarse para ser firmados: “Decidí dar una explicación pública a través de un amigo periodista, diciendo que esos tres anuncios publicitarios eran tres Grabados populares que serían firmados por mí gratuitamente a todos aquellos que los presentaran" (Barrios, 2011, p. 83). Según Cerón, lo interesante del término popular es "que alude tanto al sistema de producción y reproducción técnica, como a su apropiación cultural por fuera del arte «culto»" (Cerón, 2011, p. 103). Sin embargo, cabe señalar que algunos investigadores han relacionado erróneamente el adjetivo "populares" con el arte pop, cuando en realidad es un homenaje al grabador mexicano José Guadalupe Posada Aguilar ${ }^{4}$ famoso por sus estampas populares.

Un Grabado popular, concebido como tal, solo vendría a salir hasta el 3 de octubre de 1974 en el Diario del Caribe de Barranquilla (Imagen 2). Posteriormente vinieron los grabados como el proyecto para la exposición "Art Systems" del Institute of Contemporary Art de Londres en 1974; el Grabado popular (enviado a través del correo) desarrollado para la exposición "Latín América" en 1976, organizado por la Fundación CAyC, de Buenos Aires y la Fundación Joan Miró de Barcelona; ${ }^{5}$ el presentado en la "III Bienal" de Cali el 6 de mayo de 1976; el grabado para la Revista Laura de Bogotá en junio 1977; un nuevo grabado en el Diario del Caribe de Barranquilla el 30 de abril de 1978 y el Grabado popular Sueños con Marcel Duchamp en el Diario del Caribe de Barranquilla el 1 de octubre de 1978 (Imagen 3), en el cual nos detendremos por ser su primera cita a Duchamp.

\section{Sueños con Marcel Duchamp}

En 1978, se organiza en la ciudad de Barranquilla una exhibición colectiva en conmemoración del décimo

\footnotetext{
4 (Aguascalientes, 2 de febrero de 1852 - Ciudad de México, 20 de enero de 1913). Fue un grabador, ilustrador y caricaturista Mexicano. Considerado un artista popular que nutrió su obra del imaginario popular mexicano. Famoso por sus litografías con escenas costumbristas, de muerte, estampas populares y de crítica socio-política inspiradas en el folclore. Su personaje más famoso sería "La Calavera Garbancera" (1912) rebautizada por el muralista Diego Rivera como "La Catrina".

5 Este Grabado popular cabe dentro del movimiento del Arte Correo o Arte Postal (AP) o Mail Art.
}

aniversario de la muerte de Duchamp. Ahí se produce la génesis de su serie Sueños con Marcel Duchamp con un Grabado popular publicado el 1 de octubre de 1978 en el Diario del Caribe de Barranquilla. Se trata de un rectángulo dividido en dos partes: Al lado izquierdo y ocupando casi la mitad del espacio hay una imagen fotográfica que se corresponde con el perfil derecho del rostro de Marcel Duchamp. Al lado derecho vienen treinta rayas horizontales de color negro sobre las que viene un texto manuscrito ${ }^{6}$ con la propia letra de Barrios:

Soñé que yo tenía dos años y Marcel Duchamp había inscrito como arte mi cochecito de pasear, mi babero y una ventana de mi casa que daba sobre un mar perfectamente azul y tranquilo. Años más tarde el cochecito fue arrojado sobre el fuego, mi babero destrozado por un perro furioso y la ventana fue colocada en un hospital desde donde se veía un muro gris cubierto de humo. (Barrios, 1978).

El perfil en el Grabado popular capta el rostro de Marcel Duchamp desde la base del mentón hasta la punta de la cabeza, tratándose de un primerísimo plano, lo que implica una distancia corta, que muestra intimidad y confidencialidad respecto al personaje. En la tipología del retrato, el de perfil tiene la intención de conmemorar y fijar la imagen de un personaje de poder, riqueza o prestigio para la historia, por eso está estrechamente vinculado con las monedas y medallones. Con esta vista se idealiza la figura del personaje representado al conferirle solemnidad y autoridad. Aunque esta práctica proviene de la antigüedad, Egipto, Grecia y Roma, su máximo desarrollo se dio en la Italia renacentista, en donde el retrato aparece como género autónomo. Su forma más distintiva eran los bustos de figuras vistas de perfil contra un fondo neutro o un paisaje. La efigie de Duchamp evoca este tipo de representaciones.

El retrato usado por Barrios corresponde a una apropiación literal de la fotografía de Duchamp tomada por Man Ray en 1930 (Imagen 4), realizada con la técnica

\footnotetext{
$6 \quad$ El grabado popular venía con las líneas horizontales negras sin escribir, es decir, en blanco. Luego en cada grabado el artista manuscribía a lápiz textos diferentes. Es el único grabado popular que trae la firma impresa y un texto manuscrito.

7 Su nombre real era Emmanuel Radnitzky (Filadelfia, 27 de agosto de 1890 - París, 18 de noviembre de 1976). Aplicó el dadaísmo y el surrealismo en la fotografía.
} 


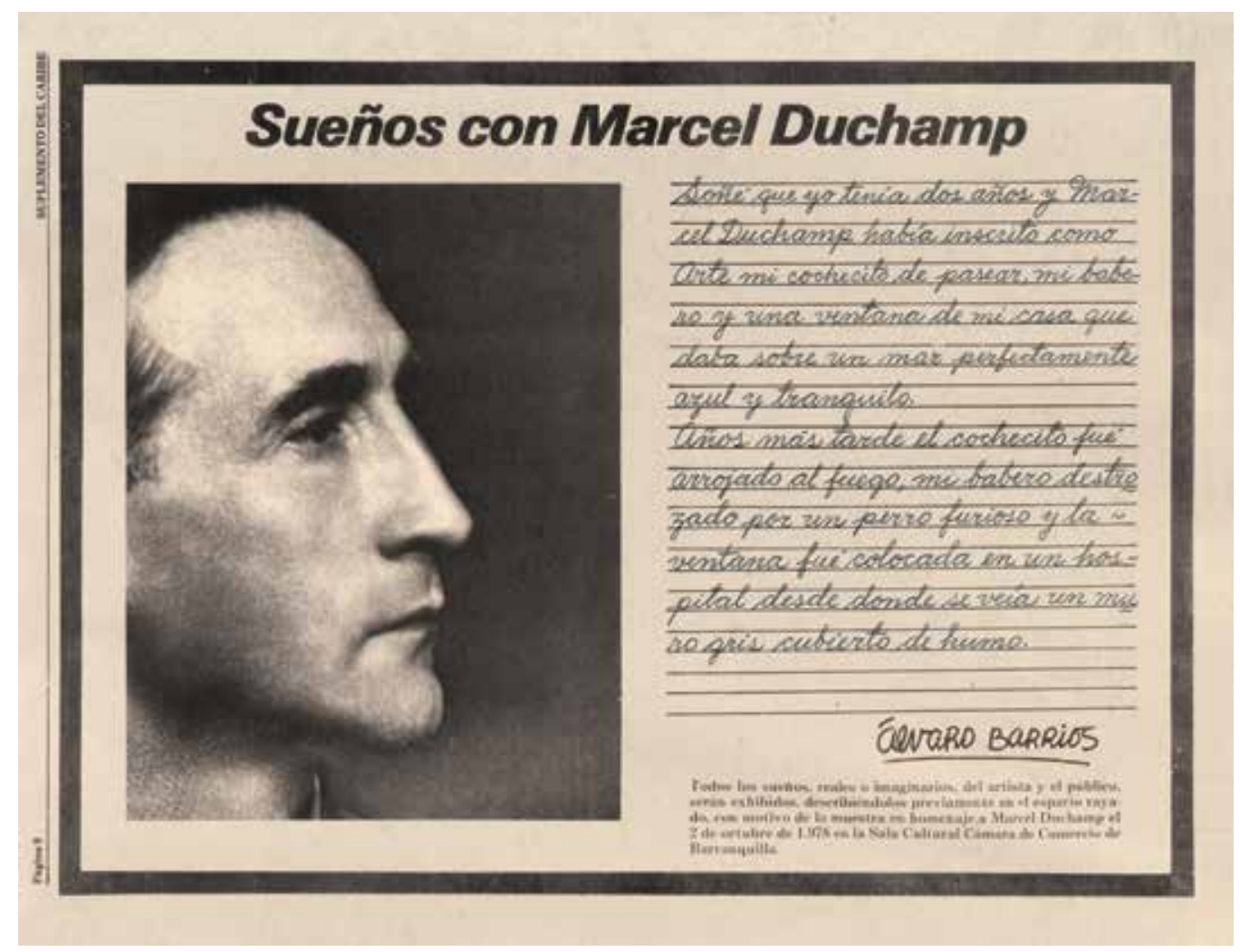

Imagen 3. Grabado popular. Sueños con Marcel Duchamp (Álvaro Barrios, 1 de octubre de 1978). Publicado en el Diario del Caribe, Barranquilla. Cortesía del artista.

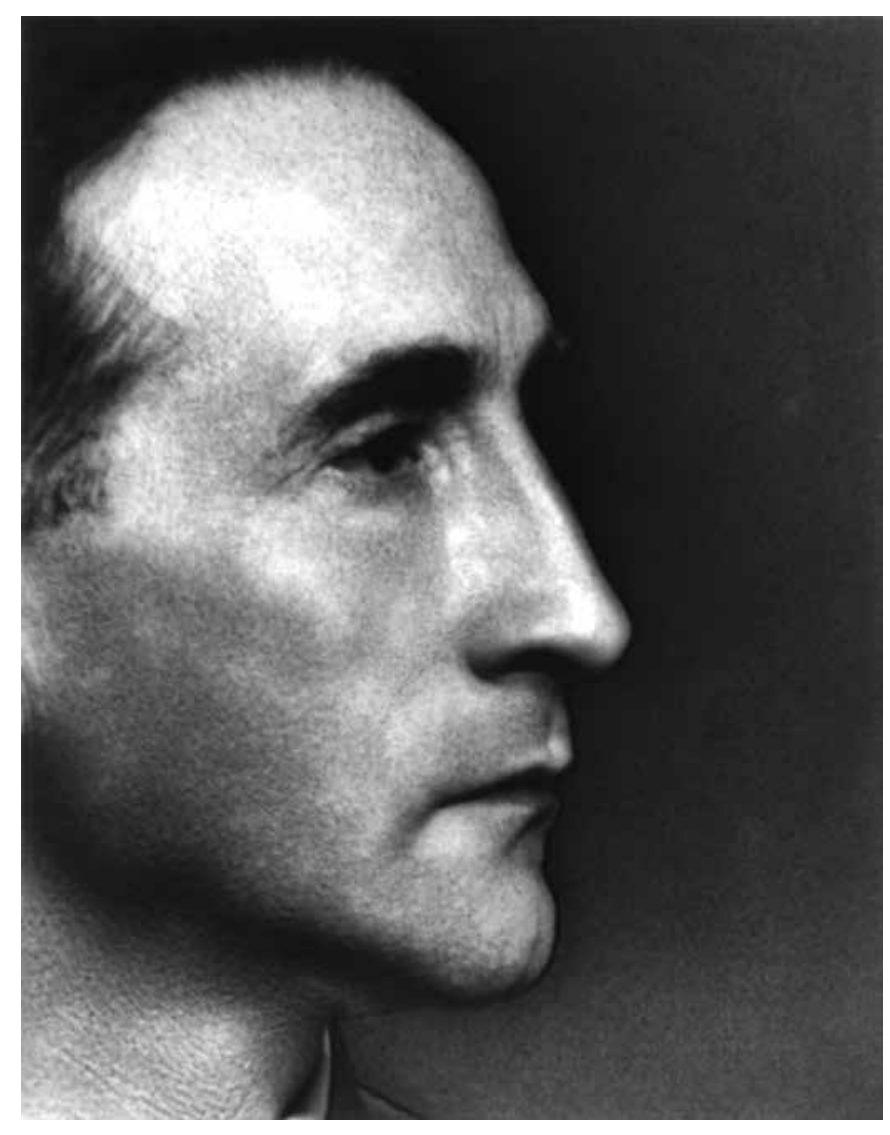

Imagen 4. Profile Portrait of Marcel Duchamp (Man Ray, 1930). Retrato solarizado. Impresión sobre gelatina de plata. $29,2 \times 22,9 \mathrm{~cm}$. Fuente: (c) 2009 Man Ray Trust / Artists Rights Society (ARS), NY / ADAGP, Paris. Imagen obtenida en la página web de la National Portrait Gallery https://npg.si.edu/exhibit/duchamp/portraits.html 


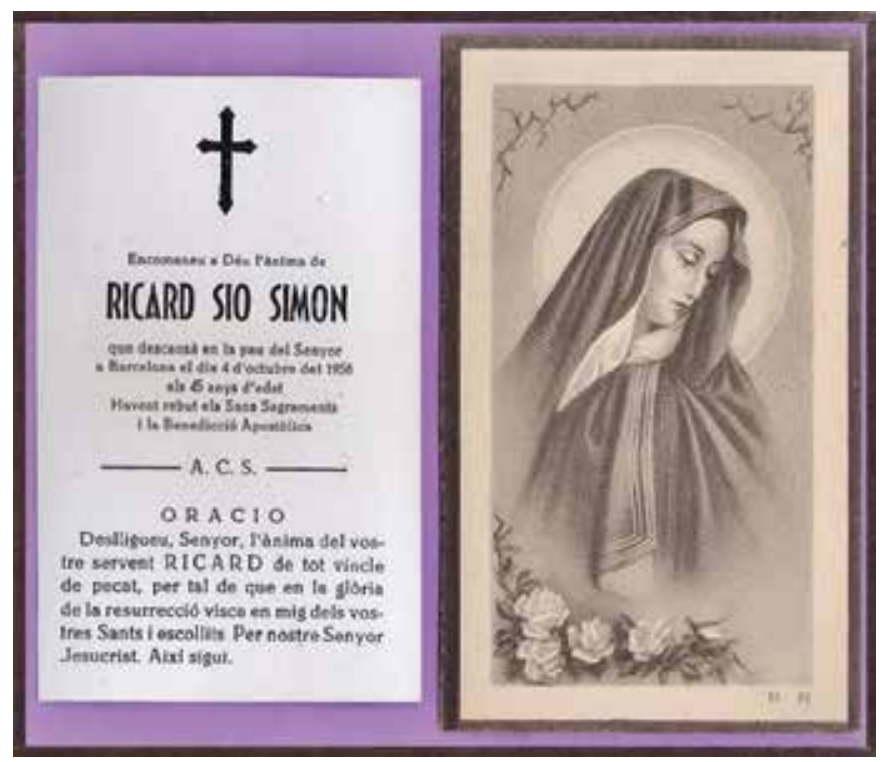

de la solarización. ${ }^{8}$ Como se puede ver, la selección de esta imagen, al ser de perfil, equipara al artista francés con personajes prestigiosos de la historia y, al tener cierta radiación luminosa, se asocia con el aura, relacionándolo simbólicamente con el halo o la aureola que se observa sobre la cabeza de personajes como Jesucristo, la virgen, los santos, los apóstoles, los ángeles o incluso objetos sagrados, que aparecen en pinturas, vidrieras o esculturas.

En Colombia, según el simbolismo funerario, un sufragio (Imagen 5) es un documento de carácter social y con un sentido piadoso que tiene el fin de expresar las condolencias, manifestar un sentimiento de pesar y solidaridad con la familia de la persona fallecida. Se vinculaban especialmente a cofradías y quién lo adquiría, pagaba el derecho a un número determinado de misas por las ánimas del purgatorio. Esta acción piadosa es una súplica a Dios para que tenga misericordia y purifique el alma de los fieles difuntos para que puedan acceder al reino de la luz y de la vida eterna. Usualmente estos documentos están divididos en dos partes: a la izquierda una imagen religiosa y a la derecha un mensaje que bien puede venir prediseñado o quien lo envía puede escribirlo. Barrios

8 Se invierten parcialmente los tonos, en donde las zonas oscuras aparecen como zonas de luz y viceversa. Apareciendo una línea o borde claro entre el cuerpo y el fondo blanco, creándose una aureola que parece el aura materializada de una persona. El relieve aumenta falsamente o se difumina, y el límite de la imagen parece rebordeado por una raya, adquiriendo similitud con el dibujo.
Imagen 5. Sufragio. Foto archivo particular.

se apropia de toda esta simbología y usa todos estos elementos tomados de la cultura popular para rendir homenaje a Marcel Duchamp. Los Sueños con Marcel Duchamp son una especie de sufragio con plegarias para que Duchamp alcance la vida eterna, quizá en el mundo del arte.

En mayo de 1980, aparece la segunda versión de Sueños con Marcel Duchamp (Imagen. 6), pero esta vez se trata de una serie hecha para su exposición en el Museo de Arte Moderno La Tertulia de la ciudad de Cali (Colombia). Barrios recuerda este hecho en el catálogo de la exposición Do it, hágalo usted mismo:

En 1978, cuando inicié la investigación sobre Marcel Duchamp, se realizó en Barranquilla una exposición en honor suyo, con motivo de los diez años de su muerte. Hice publicar un Grabado popular que consistía en una fotografía de Duchamp acompañada de unas líneas horizontales en donde el público debía escribir sus sueños, reales o imaginarios. Así comenzó la serie Sueños con Marcel Duchamp. En este grabado, la firma venía impresa y el público terminaba la obra. En el Museo La Tertulia de Cali, se exhibió una serie de unos sesenta grabados con la participación del público. (Barrios, 1997, pp. 85-86)

La serie Sueños con Marcel Duchamp se componía de entre 60 a 98 hojas volantes de forma rectangular 
denominadas como "Grabados". Son similares al publicado el 1 de octubre de 1978 y cuya descripción se ha dado anteriormente. La diferencia radica en que al lado derecho vienen treinta rayas negras, horizontales, en donde los espectadores podían escribir con su propia letra el sueño que ellos quisieran. Si Duchamp decía que "el espectador hace al cuadro" (Paz, 2008, p. 98), en esta propuesta se buscaba que el espectador hiciera parte del proceso creativo al introducir su propio sueño dentro de la obra. Sin embargo, al no tener acogida la actividad propuesta y ser banalizada por el público, el artista decide redactar y escribir de su puño y letra cada sueño, que está relacionado con la obra de Duchamp, la teoría y la historia del arte. Se trata de textos con un carácter poético, en donde el mundo de lo onírico hace su presencia. Hay diversos tipos de alucinaciones visuales en las que se diluye arbitraria y asombrosamente la realidad y la ficción. Cada grabado tiene una sentencia que pone de relieve el fetiche por la obra de arte, la firma y la imagen del artista, así como los medios y las mediaciones de la industria cultural. El lenguaje de naturaleza verbal es una herramienta esencial en su trabajo, pues en la mayoría de los casos es lo que le da materialidad al concepto. Por ello, en estos grabados, la simbiosis entre la imagen y el texto, amplían, explicitan y concretan los contenidos sígnicos.

Si se acepta que los textos que hacen parte de los Sueños con Marcel Duchamp son poéticos, ${ }^{9}$ estaríamos entrando al campo literario y, por tanto, asumiendo

9 El 20 de febrero de 2008, The Museum of Modern Art (MoMA) de New York, invitó a Álvaro Barrios a leer 40 de estos textos en el encuentro "Modern Poets", lectura denominada "Dreams About Marcel Duchamp", en conjunción con la exposición New Perspectives in Latin American Art, 1930-2006.

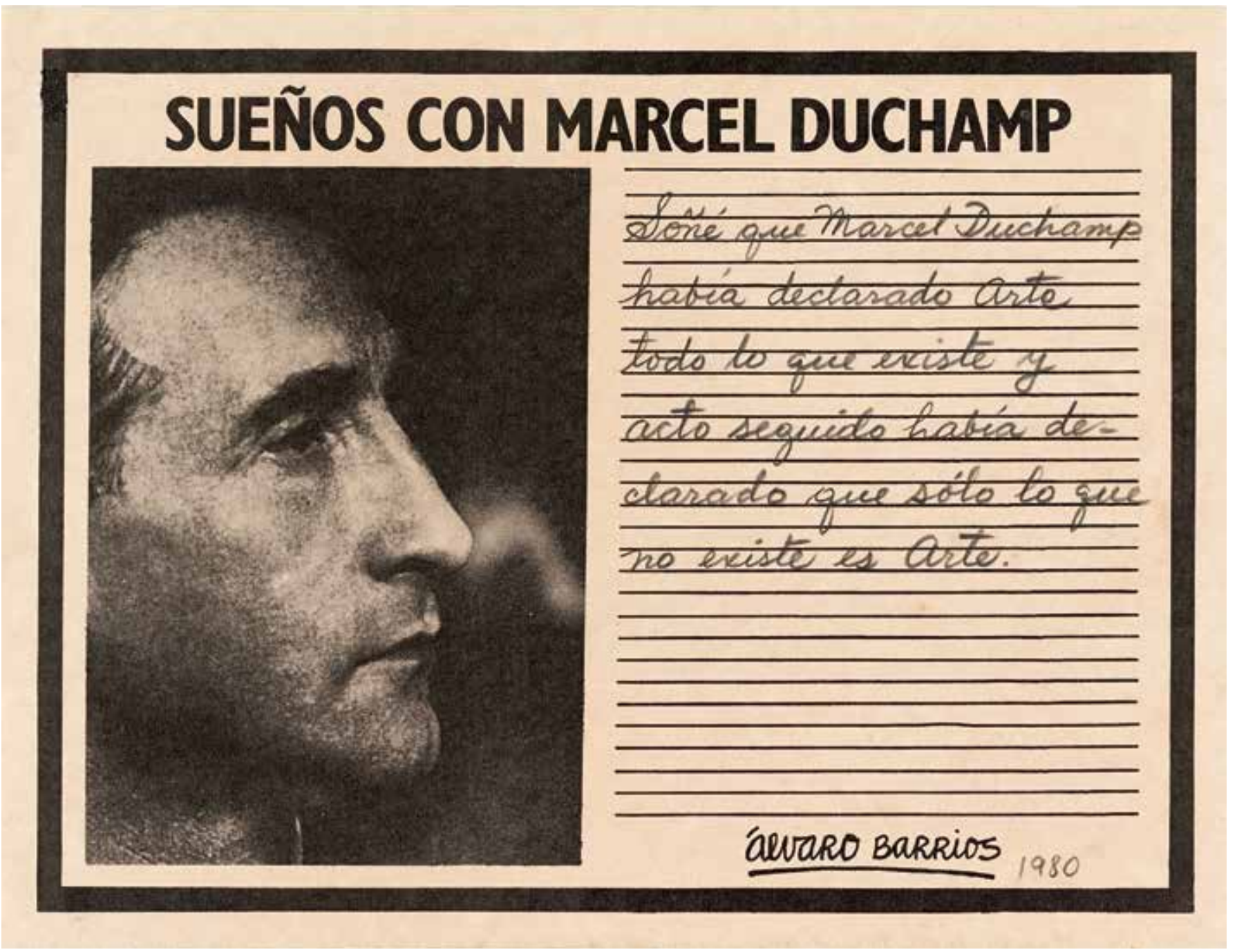

Imagen 6. Grabado popular Sueños con Marcel Duchamp (Álvaro Barrios, 1980). Litografía offset sobre papel con adiciones en lápiz. Impreso por Gráficas Lourdes (Edición ilimitada), Barranquilla, Colombia, 19,4 × 25,8 cm. Cortesía del artista. 


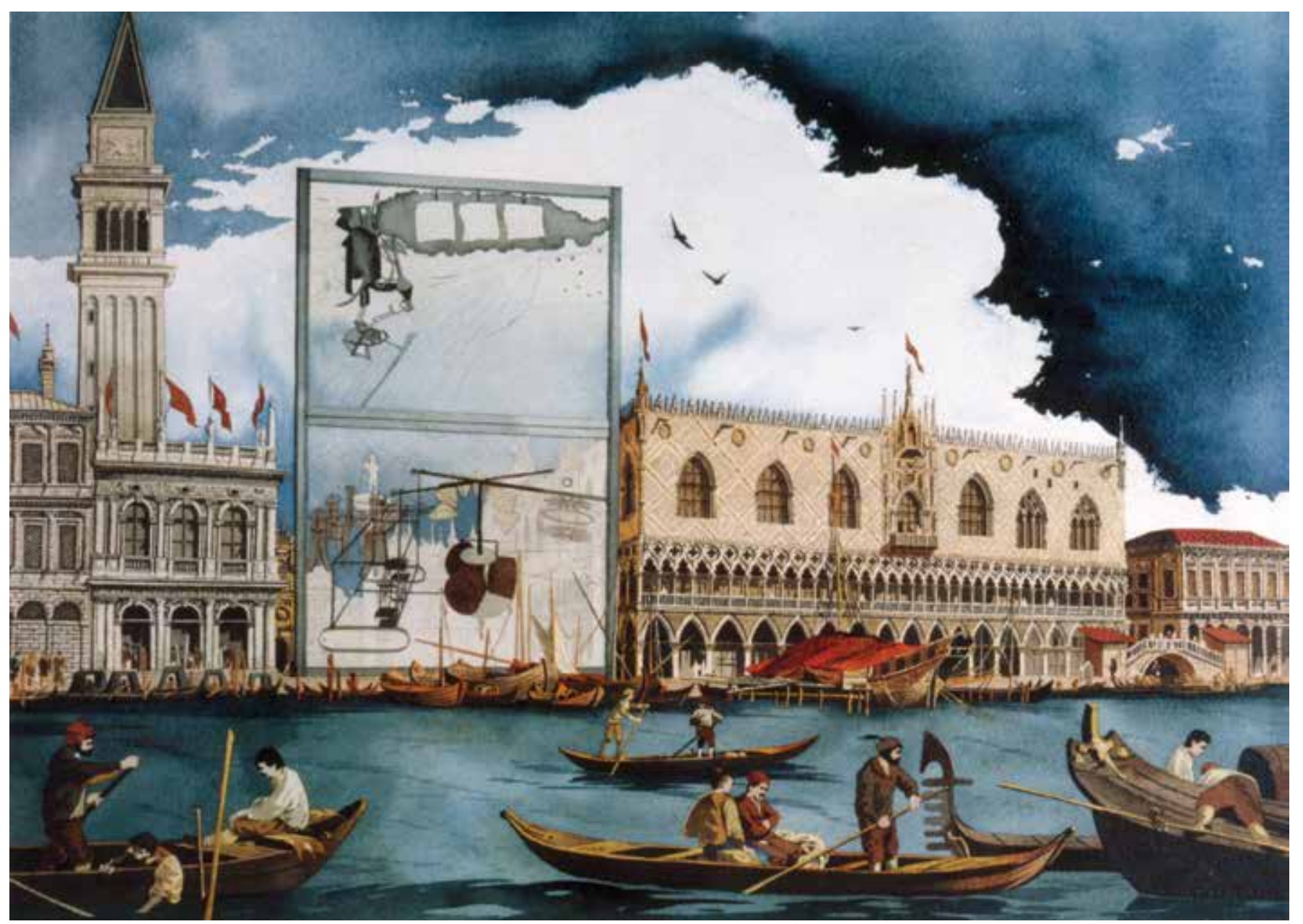

Imagen 7. Instalación de un monumento público en Venecia (Álvaro Barrios, 1983). Serigrafía, 60,5 × 78,5 cm. Banco de la República, Bogotá. Cortesía del artista.

que las referencias a los ready-made de Duchamp no son apropiaciones sino el recurso retórico de la cita, que pueden ser directas o indirectas, en este caso por alusión. José Saborit y Alberto Carriere, en su libro Retórica de la pintura (2000) definen la alusión como dar a entender o referir sin mencionar, requiriendo la necesaria participación del acervo del espectador. Esta figura retórica se da en algunos tropos: "su presencia la hemos señalado en algunos tropos, sean alusiones a individuos como antonomasias directas, de estilo o ironías paródicas, o bien alusiones a cosas y conceptos, como perífrasis o alegorías" (Saborit y Carriere, 2000, p. 439). Para los autores, la alusión se acompaña de la cita a pinturas del pasado, esto es, la reproducción total o parcial de las mismas; una repetición-variación de signos pictóricos extraídos de esas obras "....Cuando las alusiones o las citas se refieren a individuos, grupos de ellos o a cualidades de individuos, como el estilo pictórico, pueden servir -en los casos extremos- a propósitos laudatorios, respetuosos, de identificación, o por el contrario, ofensivos, menospreciativos, sarcásticos." (Saborit y Carriere,
2000, pp. 439-40). Para entender esta idea, veamos uno de los sueños manuscritos de Barrios:

Soñé que me encontraba perdido en un día del lejano futuro, como arrojado allí por una máquina del tiempo, observando en el interior de una casa en cuya sala, pobre y sencilla, una mujer usaba el cuadro "Río al anochecer con árboles en la orilla" de Rembrandt, como mesa de planchar. (1980)

Clara alusión al ready-made recíproco de Duchamp, cuyo título es Rembrandt como mesa de planchar (1919), obra en la cual se propuso usar un icono cultural como objeto cotidiano, un verdadero acto iconoclasta.

Posterior a la serie Sueños con Marcel Duchamp, vendrían unos nuevos grabados como los puestos en circulación el 27 de enero de 1981 y el 25 de mayo de 1983 en El Heraldo de Barranquilla; el 30 de julio de 1983 en El diario del Caribe de Barranquilla; el 4 de marzo de 1997 en El Espectador de Bogotá; 19 


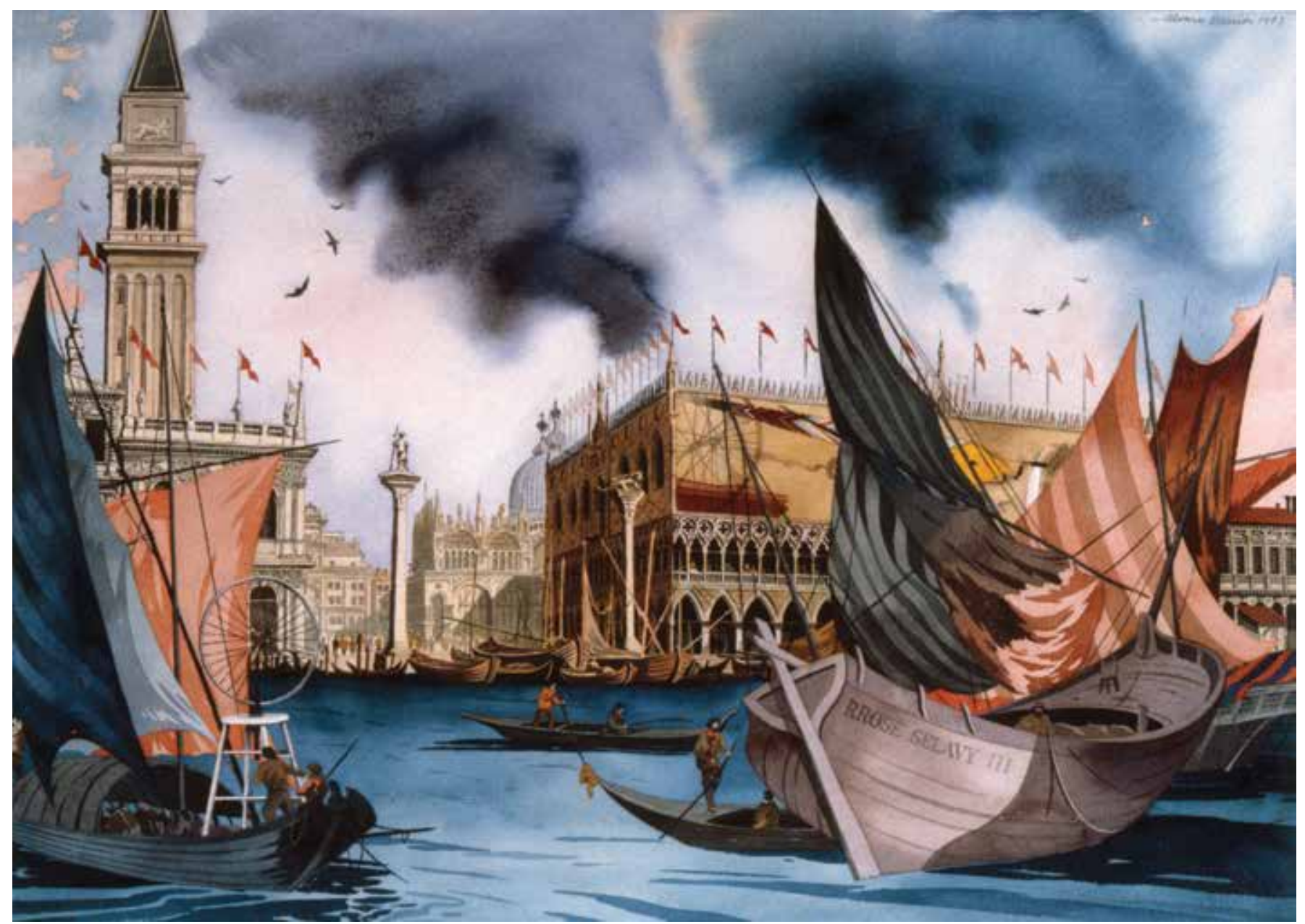

Imagen 8. Grabado popular. Llegada de una obra de Marcel Duchamp a Venecia (Álvaro Barrios, 30 de julio de 1983). Publicado en el Diario del Caribe, Barranquilla. Cortesía del artista.

de noviembre de 2008 en The Village Voice de Nueva York y el 30 de noviembre de 2008 en El Tiempo de Bogotá. Otros Grabados populares han salido como hojas volante como El martirio de San Sebastián ${ }^{10}$ de 1980, Álvaro Barrios como Marcel Duchamp como Rrose Sélavy como L.H.O.O.Q. en 1980, El mar Caribe de 2004 y iAunque Ud. no lo crea! en el 2010.

\section{Duchamp en Venecia o el viaje de los ready-made al pasado}

A comienzos de la década de los años 80 , Barrios produce una serie de Grabados populares como

10 En este grabado continua con la idea de la intervención del público siguiendo lo propuesto en sus Sueños con Marcel Duchamp en donde los espectadores escribían un sueño, aquí debían escribir un martirio real o imaginario en la líneas dispuestas para tal efecto dentro del grabado y colgarlo en una cuerda con ayuda de unas pinzas de madera.
Instalación de un monumento público en Venecia (1983) (Imagen 7) y Llegada de una obra de Marcel Duchamp a Venecia (1983) (Imagen 8) que fueron publicados en El Heraldo y en El Diario del Caribe de Barranquilla, en donde se apropia de los paisajes venecianos pintados por los italianos Giovanni Antonio Canal, conocido como Canaletto (Venecia, Serenísima República de Venecia, 7 de octubre de 1697; 19 de abril de 1768) y Bernardo Bellotto, también llamado Canaletto, el joven (Venecia, 30 de enero de 1721 Varsovia, 17 de octubre de 1780), figuras primordiales del género de la veduta (siglo XVIII). Se trata de representaciones en perspectiva de paisajes urbanos, donde se muestran con gran detalle y minuciosidad los canales, monumentos y lugares típicos de la ciudad de Venecia. Barrios se apropia de algunas obras de Canaletto como El bucintoro regresa al muelle el día de la ascensión delante del Palacio Ducale (1730), La Piazzetta y el Palacio Ducal desde la dársena de San Marcos (1735-1740) y, de Bernardo Bellotto, Vista del Gran Canal con el Puente de Rialto, visto desde el norte 
(c. 1740), para escenificar situaciones que figuraban en su serie Sueños con Marcel Duchamp.

Normalmente, los artistas apropiacionistas hacen desplazamientos temporales tomando obras del pasado y recreándolas en el presente, contemporizándolas. Lo destacado de la propuesta de Barrios es que toma obras del presente como son los ready-made de Duchamp y las introduce dentro de obras del pasado, jugando a la idea de la máquina del tiempo, generando una paradoja espacio-temporal. En entrevista que se le hizo para esta investigación, al ser cuestionado sobre este asunto, él afirma que:

Mi obra es como una máquina del tiempo. En las tiras cómicas hay una historieta que yo conocía desde antes de aprender a leer. Aparecía en el suplemento del diario La Prensa de Barranquilla, Trucutú (Alley Oop). El tema era una máquina del tiempo inventada por el científico del siglo XX, Elbert Wonmug, que le permite a un hombre de la edad de piedra viajar hacia el futuro. Trucutú termina modernizándose. También recuerdo a Brick Bradford, en esa tira cómica el protagonista se desplaza por el espacio y el tiempo en un aparato que tiene forma de trompo y que fue inventado por el profesor Kala Kopak. Mi obra es como si yo viajara en una máquina del tiempo que me permite mezclar el pasado con el presente. Esto lo he hecho a través de cincuenta años de producción artística. (Arias, 2016) ${ }^{11}$

En estos Grabados populares se observan incrustados dentro de los paisajes venecianos a los ready-made duchampianos. En algunos casos son transportados en barcazas, en otros están instalados como monumentos gigantes en las plazas como sucede con El gran vidrio (1915-1923) (Imagen 7) y Rueda de Bicicleta (1913) (Imagen 8). La palabra Rrose Sélavy ${ }^{12}$ está pintada en la proa de una embarcación y se observan las sombras de Tu m' (1918) en las fachadas de las edificaciones, entre otras.

\footnotetext{
11 La entrevista completa se puede leer en: Arias, Albeiro (2016). "Álvaro Barrios: el arte de volver a crear". En: Facetas del Periódico El Nuevo día. 24 de abril de 2016. 7c.

Consultado en: http://issuu.com/elnuevodia/docs/

facetas_24_de_abril_del_2016/3?e=0

12 Personaje femenino creado por Marcel Duchamp, que bien

puede ser su alter ego o ser simplemente un seudónimo, usado desde 1920 hasta aproximadamente 1941.
}

Hay una simbiosis iconográfica entre los ready-made de Duchamp y los paisajes de Canaletto y Bellotto. Se yuxtaponen tiempos y contextos diversos y, se presenta un maridaje entre elementos del arte conceptual y el arte clásico. Barrios recontextualiza los ready-made, al introducirlos en sus versiones de las obras pertenecientes al vedutismo italiano (siglo XVIII). No conforme con esto, en el Grabado popular publicado en El Heraldo de Barranquilla, el 25 de mayo de 1983, aparecen sobre los canales venecianos algunos objetos voladores no identificados (OVNI), agregando a su propuesta elementos de la ciencia ficción (Imagen 9).

\section{¿Qué es un Grabado popular?}

En algunos casos se trata de un "grabado" inserto o impreso dentro de un periódico, una revista o una hoja volante. Son obras perecederas debido a la mala calidad del papel prensa que tiende a oxidarse y deteriorarse rápidamente, y cuyo gramaje fluctúa entre los 40 y los $52 \mathrm{~g} / \mathrm{m} 2$ haciendo muy frágil el material. Estos insertos se aproximan a las publicidades o agregados de las grandes compañías que vienen dentro de los periódicos. Se busca aprovechar la reproductibilidad técnica y beneficiarse estratégicamente de un medio de comunicación y de sus mecanismos de distribución para lograr llegar al mayor número de espectadores, sacando a la obra de sus espacios naturales de exhibición como son las galerías y los museos. El espectador no va a la obra sino que es la obra la que llega al espectador. Además, el periódico no sufre ninguna variación en su precio comercial, lo que hace que la obra sea prácticamente gratuita. No se trata de fotografías o reproducciones de la obra sino de la obra misma a la que se le valora como única a pesar de su carácter masivo. Usualmente, después de la publicación de un grabado hay unas jornadas en las que el artista firma sin costo a todos los que traigan su grabado. Este tipo de gestos ya se habían hecho en el pasado, por ejemplo, el Manifiesto fundacional del Futurismo publicado por Filippo Tommaso Marinetti ${ }^{13}$ el 29 de febrero de 1909 en la primera página del diario francés Le Figaro.14 Sin embargo, la diferencia es que Barrios considera estos procesos de impresión como una forma de grabado. Por supuesto, los grabadores

13 (Alejandría, Egipto, 22 de diciembre de 1876 - Bellagio, Como, 2 de diciembre de 1944). Escritor y activista político italiano. 14 Foster, Hal; Bois, Yve-Alain; Krauss, Rosalind E.; Buchloh, Benjamin H. D. (2006). Arte desde 1900: modernidad, antimodernidad, posmodernidad. Madrid: Akal. 


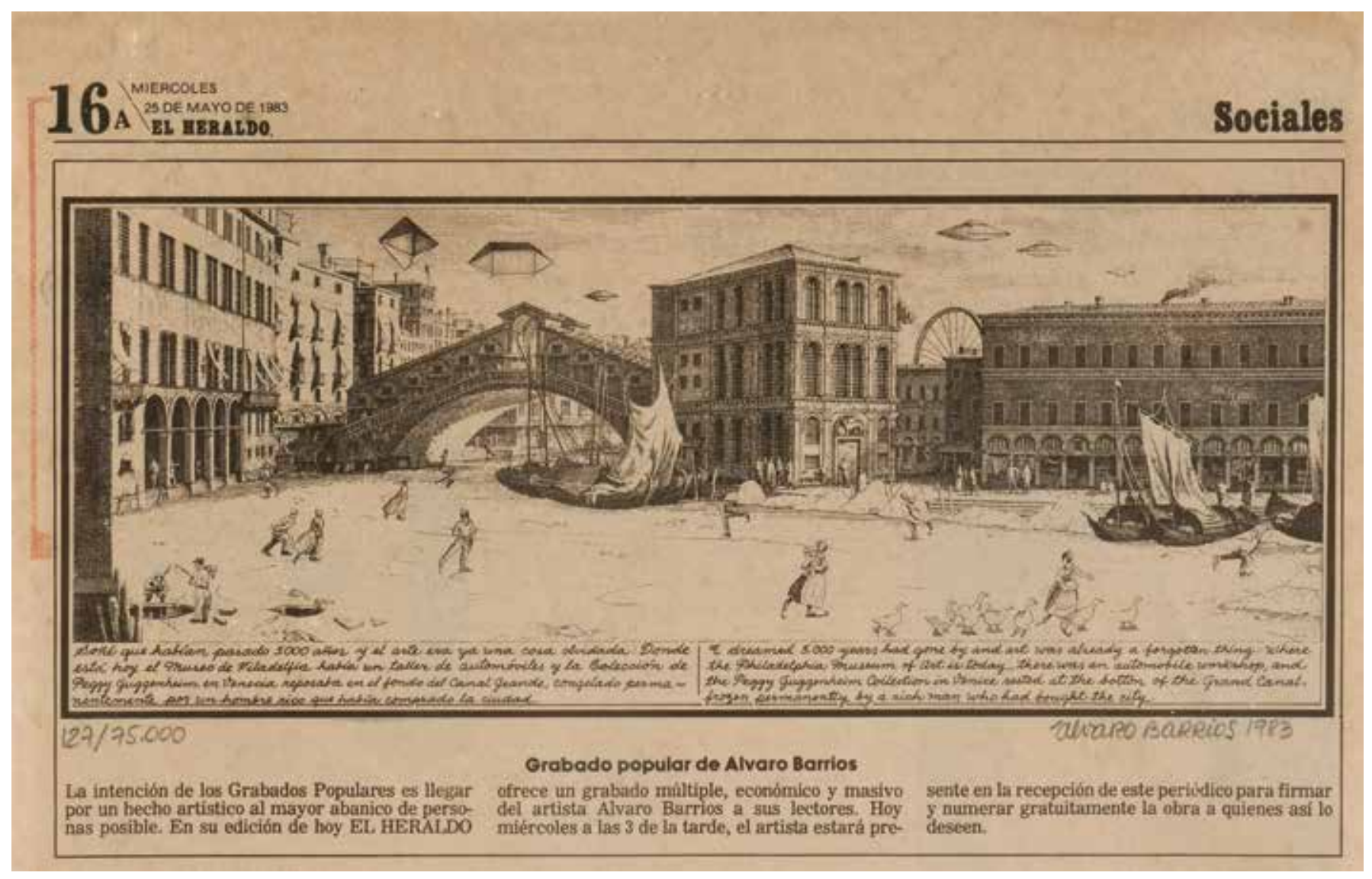

Imagen 9. Grabado Popular (Álvaro Barrios, 25 de mayo de 1983). Publicado en periódico El Heraldo, Barranquilla. Cortesía del artista.

"tradicionales" no aceptan que estos trabajos sean presentados como un grabado puesto que no hay procesos de incisión: "No son realmente grabados -acepta el artista-, e incluso los grabadores tradicionales protestan por ello y me dicen que no debo presentarlos así, pero de todas maneras es obra gráfica y el concepto de arte se ha extendido bastante" (Barrios, 2005).15 Lucy R. Lippard (1937) escribió Seis Años: La desmaterialización del objeto artístico (1973) como un texto que diera cuenta del naciente arte conceptual de finales de los 60 y principios de los 70, refiriéndose a aquel arte en donde las ideas y el discurso y no los objetos y convencionalismos formales del medio se constituirían en los principales elementos del arte. Rosalind E. Krauss, publica en 1978 su investigación sobre la escultura en el arte contemporáneo, titulada La escultura en el campo expandido, donde teoriza sobre la expansión e hibridación de lenguajes y prácticas artísticas y cómo se rompen los límites de la pintura y la escultura. Este concepto de lo extendido o lo expandido llega a otros leguajes y prácticas de la creación artística actual. Se trata al fin de cuentas de la libertad del artista/creador

15 Tomado de la Revista Cromos No.4580, 5 de diciembre de 2005. para buscar medios óptimos y más expresivos para elaborar nuevos canales para su discurso y de esta manera alejarse del formalismo. La molestia de los artistas del grabado con Barrios radica en que él no usa técnicas convencionales como la xilografía, linografía, buril, punta seca, aguafuerte, aguatinta, entre otros, sino que sus primeros Grabados populares son elaborados con la técnica de "cliché-verre", que según lo expresado por Maltese (1973):

La técnica del cliché-verre no es una técnica de grabado en cuanto que no hay paso de la tinta de una matriz a la hoja por presión, sino solamente una aplicación del procedimiento fotográfico al original. Una placa de vidrio se recubre completamente con una capa de tinta tipográfica, que se deja secar. El artista realiza el dibujo haciendo una incisión en esta capa opaca con una punta, como si rayara el barniz que cubre la placa de cobre preparada para el aguafuerte. Una vez que la luz pasa por donde la punta ha puesto al descubierto el vidrio y no pasa por los otros puntos, aplicando a la parte posterior de la placa de vidrio una hoja de papel sensible, se obtiene un negativo fotográfico en el que todavía los rasgos incisos resultan 
negros sobre fondo blanco. Las hojas obtenidas con este procedimiento recuerdan un poco dibujos a pluma y a tinta china. (Maltese, 1973, p. 235)

En el mismo sentido en el libro Introducción general al arte16 dice:

El motivo en esta técnica no pasa de una matriz al papel por presión sino que se logra por aplicación del procedimiento fotográfico al diseño original (con lo que no es un verdadero grabado). Para ello se recubre una lámina de vidrio totalmente con tinta tipográfica, que se deja secar. Sobre ella el artista realiza el dibujo con una "punta", como en el caso del barniz del aguafuerte. Al pasar la luz por las partes que la tinta ha puesto al descubierto en la lámina de vidrio, se obtiene sobre un papel sensible un negativo fotográfico en el que los trazos resultan negros sobre fondo blanco. El efecto es como el de dibujo o tinta china, evidentemente influenciado por la fotografía. (1980, p. 384)

En el folleto de la I Trienal Poli/Gráfica de San Juan: América Latina y el Caribe (2004), describen así el trabajo del barranquillero:

En el taller de xilografía coexisten los procesos de dibujar y cortar la plancha, e imprimirla. Todo puede realizarlo una misma persona, pero a menudo las funciones aparecen separadas y el crédito mayor lo tiene el que dibuja y corta. El impresor pasa a un segundo plano aun cuando el resultado final depende de su pericia. Álvaro Barrios ironiza esta jerarquización cuando realiza sus "grabados populares" en periódicos. Barrios funciona como dibujante y el rotativo - un ente mecánico-, como impresor. Firma las hojas del periódico, las enumera de acuerdo con la cantidad de ejemplares de la edición (1/30,000, por ejemplo) y las exhibe. Hasta presenta las páginas con errores de impresión como "Pruebas de artista"..17

Barrios conocía las técnicas tradicionales del grabado por lo que su propuesta no fue un simple arribismo o facilismo ni llegó como un intruso aunque sí por azar.

16 VVAA.- Introducción general al arte. (1980). Madrid: Istmo. 17 Folleto. I Trienal Poli/Gráfica de San Juan: América Latina y el Caribe. San Juan de Puerto Rico. 4 de diciembre de 2004. Editor Elvis Fuentes Rodríguez. Consultado en: https://static1.squarespace. com/static/55009c35e4b0113109046abc/t/55f72921e4b0d9c41fOfbbe0/1442261281672/BOLETINes+1ra+TRIENAL.pdf
Su propuesta fue una rebelión conceptual que en un principio pasó desapercibida en el país. Sin embargo, en el extranjero fue mejor entendida y valorada. El tiempo terminó dándole la razón. Dice Barrios que en 1979 el jurado de la I Trienal de Buenos Aires le reconoció como el inventor del Grabado popular, aunque él no lo considera un mérito especial. Lo cierto es que expandió el concepto del grabado, dilatándolo, ampliándolo, desestimando sus límites, sus procesos. Si lo específico del grabado es dibujar con diversos objetos una imagen sobre una matriz dejando una huella que después alberga tinta y se traslada por presión a otra superficie como papel o tela para obtener varias reproducciones de la estampa, Barrios se sale de ese soporte, rompe los moldes y va en otra dirección. Él no busca la experimentación formal de sus predecesores sino que asume una postura crítica frente a la práctica del grabado y al grabado mismo, incluso, sobre el concepto de edición original: "son sus trabajos asociados a la idea de inserción, como sus Grabados populares, los que llegan a modular más agudamente una aproximación a una reproductibilidad sin límite y los que revelarán y desmantelarán la ficción del «efecto de originalidad» aplicado habitualmente en estos casos" (Cerón, 2011, p. 90).

Cabe ahora interrogarnos ¿qué es lo que cuestionan los Grabados populares? Barrios lo explica para el periódico El Tiempo:

Los Grabados populares de Barrios son todo lo contrario de lo que suelen hacer otros, pues las ediciones son de miles (uno tradicional acaso llega a cien). El papel es frágil y se oxida fácilmente. Además, tiene todos los defectos de una impresión en periódico. Esto contradice la idea elitista que el público tenía en su momento de los grabados: que eran ediciones pequeñas y costosas, tanto que terminaron teniendo precios casi tan altos como las piezas únicas [...] toda una revolución para la época [...] Yo me estaba apropiando del trabajo de la máquina y empecé a crear una teoría de este tipo de grabado frente al grabado tradicional, que tiene otras condiciones, como la intervención de la mano, dice Barrios. (El Tiempo, 2008)

En su libro Orígenes del arte conceptual en Colombia se reafirma en esta idea:

...la idea de los Grabados populares es cuestionar la presencia del grabado tradicional en el arte contemporáneo, la dirección que este fue tomando cuando en sus inicios tenía como misión popularizar 


\begin{tabular}{|l|l|l|}
\hline Técnica & $\begin{array}{l}\text { Xilografía, a buril, punta seca, linografía, } \\
\text { calcografía, mezzotinta, aguafuerte, agua- } \\
\text { tinta, etc. }\end{array}$ & $\begin{array}{l}\text { Procedimientos fotográficos, digitales } \\
\text { o láser }\end{array}$ \\
\hline Papel & Muy finos y duraderos & Papeles ordinarios/ periódico \\
\hline Tintas & Finas & Ordinarias y comunes \\
\hline Edición & Limitada/Única impresión & Ilimitada/reimpresiones \\
\hline $\begin{array}{l}\text { Exhibición y } \\
\text { distribución }\end{array}$ & Dentro del campo institucional & Fuera del campo institucional \\
\hline Cualidades & Museos/ galerías/ & Periódicos/ revistas/ hojas volantes \\
\hline & Subastas & Concepto \\
\hline
\end{tabular}

Tabla 1. Cuadro comparativo entre los grabados tradicionales y los Grabados populares. Cuadro comparativo entre los grabados tradicionales y los Grabados populares de A. Barrios. Elaboración: Albeiro Arias (2019).

el arte entre las personas que no tenían acceso a la pieza única. Pero los grandes artistas, en especial los internacionales, terminaron realizando grabados a precios muy altos, sobre todo cuando saben que en esas obras están plasmando un trabajo de gran importancia conceptual... (Barrios, 2011, p. 84).

En entrevista personal para esta investigación, Barrios recuerda que el grabado dentro del arte nació como una propuesta que pretendía reproducir una misma obra con el objetivo de llegar a un mayor número de personas y a un precio mucho más bajo que una obra única:

Lo diferente que tiene lo mío es el uso de la palabra grabado para algo en lo cual el artista no trabaja a mano la plancha sino que esta se hace mecánicamente. Busco además cuestionar el grabado tradicional dentro del ámbito del arte contemporáneo, porque perdió el norte que se había propuesto, que era hacer del arte algo popular y terminaron siendo ediciones muy limitadas, costosas y valuadas por una firma. (Arias, 2016) ${ }^{18}$

Con base en lo expuesto por el artista y en nuestra apreciación, podemos hacer una distinción entre los

18 Arias, A. (2016). Entrevista a Álvaro Barrios, vía telefónica hecha el 13 de mayo de 2016. Ibagué-Barranquilla, Colombia. grabados tradicionales y Grabados populares: en los primeros la firma es esencial porque le otorga valor económico, las tintas y los papeles son finos y duraderos, su edición es limitada y se mueve dentro del campo institucional. En el Grabado popular la firma es gratuita, se usa papel periódico, por lo tanto, su duración es temporal porque se oxida y pierde consistencia, su edición es ilimitada, no solo por las numerosas ediciones que han llegado a alcanzar más de 400.000 ejemplares sino porque un mismo grabado podría eventualmente ser reimpreso. Finalmente, desborda el campo de circulación institucional no sólo en su exhibición sino en su distribución.

El siguiente interrogante sería ¿y por qué con el tiempo han cobrado mayor validez los Grabados populares? La crisis de los postulados del arte moderno como la pureza de géneros, la autonomía, los límites y la llegada de las nuevas posturas de la posmodernidad como la hibridación de géneros, hicieron que los Grabados populares adquirieran validez. Trascendieron los principios del grabado moderno. No es de extrañar que el MoMA adquiriera los grabados de Barrios, teniendo en cuenta que fue allí precisamente que Leo Steinberg pronunció su famosa conferencia "Other Criteria" en 1968, donde se habló por primera vez del estado posmoderno de las artes visuales. 


\section{Propuestas conceptuales de Duchamp en los Grabados populares de Barrios}

Hay que aclarar que, aunque los primeros grabados se publican en 1972, y su primera cita a Duchamp inicia en 1978, Barrios desde 1964, conoce el pensamiento de Duchamp gracias al libro The Artist's Voice: Talks With Seventeen Modern Artists (1962) de Katharine Kuh (Barrios, 2011, pp. 70-71).

¿Cómo se relacionan los Grabados populares con los ready-made? En el Dictionnaire abrégé du Surréalisme (Paris, Galerie des Beaux-Arts, 1938) editado por André Breton y Paul Éluard, aparece una definición de readymade, atribuida a Marcel Duchamp: “objet usuel promu à la dignité d'œuvre d'art par le simple choix de l'artiste" (p. 23). ${ }^{19}$ Duchamp hacía de un objeto manufacturado una escultura. Ya no era necesario esculpir con la mano sino el simple hecho de ser designada así por el artista, el gesto. Eso son los Grabados populares, un gesto. El que le concede el mismo valor al cliché hecho por una máquina que a una talla hecha a mano por un artista. Barrios logra que sus ideas y conceptualización sobre el grabado sean más importantes que su realización material y sus aspectos formales. Sus grabados no deben ser interpretados como objetos de contemplación creados por la mano de un artista sino como objetos para la especulación intelectual. Barrios saca a sus grabados del museo y las galerías y los lleva a los medios masivos de comunicación; para el barranquiIlero, lo importante no es la temática ni la forma sino el concepto, la idea. Si algunos artistas usaron el grabado para la experimentación formal, Barrios usó el grabado para la experimentación conceptual.

\section{Referencias}

Arias, A. (04 de abril de 2016). Álvaro Barrios: el arte de volver a crear. Facetas. Periódico El Nuevo día, p. 7c. Recuperado de: http://issuu.com/elnuevodia/docs/ facetas_24_de_abril_del_2016/3?e=0

Arias, A. (2017). Álvaro Barrios: Citas y apropiaciones de los ready-made de Marcel Duchamp (1978- 2013). Tesis inédita de doctorado. Facultad de Artes, Pontificia Universidad Católica de Chile. Santiago de Chile.

19 "un objeto ordinario elevado a la dignidad de obra de arte por la pura elección de un artista", traducción propia.
Barrios, Á. (1981). Génesis de una idea. Revista del Arte y la Arquitectura en América Latina, 2(6), pp. 48-54. Recuperado de: http://icaadocs.mfah.org/icaadocs/ ELARCHIVO/RegistroCompleto/tabid/99/doc/1079828/ language/es-MX/Default.aspx

(2011). Orígenes del arte conceptual en Colombia (Segunda ed.). Medellín, Colombia: Fondo Editorial Museo de Antioquia.

Breton, A., Éluard, P. (1938). Dictionnaire abrégé du Surréalisme. Paris: Galerie des Beaux-Arts.

Catálogo. (4 Diciembre 2004 - 6 Marzo 2005). I Trienal Poli/Gráfica de San Juan: América Latina y el Caribe (Trans/Migrations: The Graphic Arts as Contemporary Artistic Practice). E. Fuentes Rodríguez (Ed.) San Juan de Puerto Rico: Programa de Artes Plásticas del Instituto de Cultura Puertorriqueña. Recuperado de: https://static1. squarespace.com/static/55009c35e4b0113109046abc/ t/55f72921e4b0d9c41f0fbbe0/1442261281672/ BOLETINes+1ra+TRIENAL.pdf

Cerón, J. (2011). Sueños con Álvaro Barrios. Bogotá: Ediciones Jaime Vargas.

Duchamp, M. (1978). Escritos. Duchamp du Signe. (J. Elías, \& C. Hesse, Trads.) Barcelona: Gustavo Gili, S.A.

Foster, H., Bois, Y.-A., Krauss, R. E., \& Buchloh, B. H. (2006). Arte desde 1900: modernidad, antimodernidad, posmodernidad. Madrid: Akal.

Martín Prada, J. (2001). La apropiación posmoderna: arte, práctica apropiacionista y teoría de la posmodernidad. Madrid: Editorial Fundamentos.

El Tiempo. (30 de noviembre de 2008). Barrios bate marca con sus grabados. Bogotá. Recuperado de: http://www.eltiempo.com/archivo/documento/ MAM-3212947

Sáez de Ibarra, M. B. (2013). Álvaro Barrios: la leyenda del sueño, revisión retrospectiva. (Catálogo exposición celebrada en el Museo de Arte del Banco de la República, Bogotá, 27 de noviembre de 2013 al 3 de marzo de 2014). Bogotá: Museo de Arte del Banco de la República.

Vides Celis, E. (1997). Obra gráfica de Álvaro Barrios. Bogotá: Banco de la República, Biblioteca Luis Ángel Arango. 